\title{
Bacteremic patients in the Emergency Department - how do they present and what is the diagnostic validity of temperature, CRP and SIRS?
}

\author{
Katrine Prier Lindvig ${ }^{1 *}$, Stig Lønberg Nielsen², Daniel Henriksen', Thøger Gorm Jensen³, Hans Jørn Kolmos³, \\ Court Pedersen², Annmarie Touborg Lassen ${ }^{1}$
}

From Proceedings of the 5th Danish Emergency Medicine Conference

Aarhus, Denmark. 18-19 April 2013

\section{Background}

It might be a clinical challenge to identify patients with bacteremia. Blood cultures are often ordered based on the symptoms of fever and chills. Detailed knowledge of the clinical presentation of acute medical patients will improve the identification of bacteremic patients. The aim of this study was to evaluate the diagnostic value of temperature $\left({ }^{\circ} \mathrm{C}\right)$, C-reactive-protein (CRP), and Systemic Inflammatory Response Syndrome (SIRS) in bacteremic patients admitted to the Medical Emergency Department (ED).

\section{Methods}

A population based cohort study including all adult $(>15$ years old) first-time admissions at the ED at Odense University Hospital between 1/8 2009-31/8 2011. A bacteremic patient was defined as having a positive blood culture drawn within the first two days after admission. All patients had their bloodpressure, pulse rate, respiratory frequency, oxygen saturation, level of consciousness measured and standard blood samples drawn at arrival.

\section{Results}

We included 11.996 acute medical patients and excluded31 patients because of missing identification data. Median age was 66 years (range 15-103), and 5499
(45.0\%) were male. In total 5503 (45.9\%) patients had blood cultures performed, of which 418 (7.6\%) were culture positive, defining bacteremia. Of the 418 bacteremic patients, 381 had a temperature measured at arrival; hereof $130(34.1 \%)$ patients had a normal rectal temperature $\left(36.0^{\circ}-38.0^{\circ} \mathrm{C}\right)$ registered, $116(28 \%)$ had a $\mathrm{CRP}<100 \mathrm{mg} / \mathrm{dL}$, and 102 (24\%) did not fulfil the criteria for SIRS. The most frequent species among the 130 patients with normal temperature were E.coli $n=39$ (30\%), S.aureus $n=19$ (15\%) and S.pneumoniae $n=13$ (10\%). The ROC-area for CRP and temperature as predictors of bacteraemia were 0.67 and 0.75 respectively, representing a sensitivity of 0.66 and a specificity of 0.82 with a CPR-cut-off-value of 100 , and a sensitivity of 0.59 and a specificity of 0.84 with a temperature-cut-off-value of $\geq 38.0^{\circ} \mathrm{C}$.

\section{Conclusion}

$34 \%$ of the acute medical bacteremic patients had a normal temperature when arriving at the hospital, $32 \%$ had a CRP below $100 \mathrm{mg} / \mathrm{dL}$ and $24 \%$ did not fulfil the criteria for SIRS. If the decision to order blood cultures were based on either temperature, CRP or SIRS, one third of all bacteremic patients would have been overlooked.

\footnotetext{
* Correspondence: klindvig4@gmail.com

'Department of Emergency Medicine Odense University Hospital, Denmark

Full list of author information is available at the end of the article
}

(c) 2013 Lindvig et al; licensee BioMed Central Ltd. This is an Open Access article distributed under the terms of the Creative Commons Attribution License (http://creativecommons.org/licenses/by/2.0), which permits unrestricted use, distribution, and reproduction in any medium, provided the original work is properly cited. 


\section{Authors' details}

'Department of Emergency Medicine Odense University Hospital, Denmark.

${ }^{2}$ Department of Infectious Diseases Odense University Hospital, Denmark.

${ }^{3}$ Department of Clinical Microbiology Odense University Hospital, Denmark.

Published: 9 September 2013

doi:10.1186/1757-7241-21-S2-A19

Cite this article as: Lindvig et al.: Bacteremic patients in the Emergency

Department - how do they present and what is the diagnostic validity

of temperature, CRP and SIRS? Scandinavian Journal of Trauma

Resuscitation and Emergency Medicine 2013 21(Suppl 2):A19.

Submit your next manuscript to BioMed Central and take full advantage of:

- Convenient online submission

- Thorough peer review

- No space constraints or color figure charges

- Immediate publication on acceptance

- Inclusion in PubMed, CAS, Scopus and Google Scholar

- Research which is freely available for redistribution

Submit your manuscript at www.biomedcentral.com/submit 